\title{
THE GENEALOGY OF MUSLIM RADICALISM IN INDONESIA A Study of the Roots and Characteristics of the Padri Movement
}

\author{
Abd A'la \\ IAIN Sunan Ampel Surabaya, Indonesia
}

\begin{abstract}
This paper will trace the roots of religious radicalism in Indonesia with the Padri movement as the case in point. It argues that the history of the Padri movement is complex and multifaceted. Nevertheless, it seems to be clear that the Padri movement was in many ways a reincarnation of its counterpart in the Arabian Peninsula, the Wahharyovement, even though it was not a perfect replica of the latter. While the two shared some similarities, they were also quite different in other respects. The historical passage of the Padris was therefore not the same as that of the Wahharis. Each movement had its own dimensions and peculiarities according to its particular context and setting. Despite these differences, both were united by the same objective; they were radical in their determination to establish what they considered the purest version of Islam, and both manipulated religious symbols in pursuit of their political agendas.
\end{abstract}

Keywords: Padri movement, fundamentalism, radicalism, Minangkabau, Wahhałism.

\section{Introduction}

Almost all historians agree that Islam in the Malay Archipelago - a large part of which subsequently became known as Indonesia - was disseminated in a peaceful process. The people of the archipelago accepted the religion of Islam wholeheartedly without any pressure or compulsion. To a certain extent, these people even treated Islam as belonging to their own culture, seeing striking similarities between the new religion and existing local traditions. This peaceful process, which 
characterized the advent of Islam and its dissemination in the archipelago, stands as a kind of historical hallmark in Indonesia.

Nonetheless, the advent of Islam and its continued existence in the region were not always marked by peace and harmony. At certain phases of its development and in certain areas of the archipelago, Islam -or to be more precise certain individuals and groups representing Islam- were involved in violent acts. Among the first groups that used violence, not only against non-Muslims but also against Muslims, was the Padri movement. ${ }^{1}$

Even a superficial analysis of this movement reveals that the violent acts that its proponents committed over time were the result not only of a shallow understanding of religion but also of their political ideology. In other words, these violent acts were not born out of the blue.

The Padris' uncertain interpretation of Islam was constructed in such a way that violence might be legitimized. It was here that the Padris found a perfect concurrence with the ideology of the Wahhabi> movement in the Arabian Peninsula.

On the historical link between the two movements, Benda has rightly pointed out that what he calls the Pax Wabhattracted the attention of many Muslims in the Indonesian archipelago and exerted a serious influence on them. This Arabian dogma was also able to transcend the doctrinal differences existing among its Indonesian adherents and united them in the pursuance for their ideological cause. $^{2}$

Wahha $\nrightarrow$ 丹eliefs were first brought to Indonesia by early pilgrims, who upon their return from the Holy Land disseminated the ideas, imbued them with their own interpretative touches and sought to ingrain them in the minds and souls of their followers.

This paper aims at investigating the complexity involved in the phenomenon of the Padri movement. It will try first to trace the characteristics of the Padri movement, shedding light on its

\footnotetext{
${ }^{1}$ See Azyumardi Azra, "Islamic Radical Movement in Indonesia," (Paper presented at the Conference "The Link-up Terrorism in Southeast Asia," Center for Moderate Muslim, Jakarta 2006). See also Azyumardi Azra, "Salafisme," Republika, 14 April 2005.

2 See Harry J. Benda, The Crescent and the Rising Sun: Indonesian Islam under The Japanese Occupation 1942-1945 (Netherlands: W. van Hoeve Ltd. - The Hague and Bandung, 1958), p. 73.
} 
background and mode of religiosity, and then highlighting its acts of violence. Then it is necessary to demonstrate the relationship between this movement and the Wahharimovement since this relationship formed a central part of the Padri's ideological tenets. The study holds that there was indeed such relationship. Although the Padri movement might have developed its own normative values, agendas and obsessions, an ideological and perhaps pedagogical relationship remains possible. While there might have been some kind of discontinuity between the two movements, this discontinuity remains to be proven.

The violence that the Padri movement committed was not simply ideological or theological in nature. I distinguish between self-defense "violence," ad hoc violence, violence committed for non-religious reasons, and religious violence. The Padri movement committed all forms violence, although I regard the first form not as violence in a pejorative sense.

\section{Islam in Minangkabau}

Various views have been expressed concerning the precise period of the arrival of Islam in Minangkabau, the region in Western Sumatra where the Padri movement flourished. One of these views holds that Islam -notably in its Sufistic form- was already established in Minangkabau in the $14^{\text {th }}$ century. ${ }^{3}$ This view, however, lacks accurate evidence and is ultimately unconvincing. It is unlikely that during that period of time Islam was already in Minangkabau because the whole region was overwhelmingly Hindu and was controlled by Adityawarman, the viceroy of the strong Javanese Hindu Kingdom called Majapahit. ${ }^{4}$ In all likelihood, Islam arrived and then flourished in Minangkabau around the $16^{\text {th }}$ century. Quoting Pires, Ricklefs maintains that by that time the king of Minangkabau and hundreds of his relatives and partisans had already embraced Islam. The masses in Minangkabau then followed in the footsteps of their leaders. ${ }^{5}$ This view is considered more accurate, and receives unequivocal approval

\footnotetext{
${ }^{3}$ See Melissa Rimac, "Matrinial Minangkabau," in http://www.practitionerdirectory.com.au/natural_health_article?cid=751\&pid $=17365$.

4 See M. C. Ricklefs, Sejarah Modern Indonesia 1200-2004 Jakarta: PT Serambi Ilmu Semesta, 2005), p. 302.

5 Ibid., p. 35.
} 
from the historian Dobbin, who believes that the conversion of the people of Minangkabau to Islam took place during the period at the end of the $16^{\text {th }}$ century and the beginning of the $17^{\text {th }}$ century when the Muslim Kingdom of Aceh dominated the whole of Sumatra. ${ }^{6}$

Another view says that Islam came to Mingankabau in the $15^{\text {th }}$ century. This view is based on a local legend called tambo which highlights the idea of creation in the world-view of the Minangkabau. ${ }^{7}$ The tambo has it that the world of Minangkabau was created from, as Azra quotes, "the light of Muhammad" during the same time that two other worlds, namely "Benua Ruhum," (the Turkish Ottoman Empire), and the "Benua Cina" (the Chinese continent) were created. ${ }^{8}$ Azra argues that after the Ottoman Empire conquered Constantinople in the second half of the $15^{\text {th }}$ century - in 1453 to be precise - the Ottomans established their political and cultural supremacy over some parts of the Malay archipelago. ${ }^{9}$ By associating themselves with the Islamic Ottoman Empire, the people of Minangkabau seem to have identified themselves as Muslims.

Because of these conflicting historical accounts, it preferable to focus on the mode and process of the Islamisation of this region rather than to argue about the exact date of Islam's arrival. Suffice it to say that Islam might have come to Minangkabau during the $14^{\text {th }}$ century, but it was only in the $16^{\text {th }}$ century that Islam was established as the religion of the majority. What is of paramount importance is to note that, once it was established as the public religion as it were, Islam became a monumental phenomenon that attracted not only the

\footnotetext{
6 Christine Dobbin, “Tuanku Imam Bondjol (1772-1864)," Indonesia Vol. 13 (April 1972), p. 5.

7 "The World of Minangkabau" is regarded as an integral concept representing the overall system, institution and the life of people of Minangkabau. The world of Minangkabau consists of three domains, namely lu(h)ak called Agam, Limapuluh Kota, and Tanah Datar. Subsequently, the world of Minangkabau also consists of Solok known previously as Kubung XIII, and IX Koto. These four regions were known as Padang Darat. Each region has what they call nagari numbering at the time 600. See Elisabeth E. Graves, Asal Usul Elite Minangkaban Modern: Respons terhadap Belanda Abad XIX/XX, Translation (Jakarta: Yayasan Obor Indonesia, 2007), pp. 1-5; pp. 30-31.
}

8 Azyumardi Azra, Jaringan Ulama Timur Tengah dan Kepulauan Nusantara Abad XVII dan XVIII (Bandung: Penerbit Mizan, 1994), p. 45.

${ }^{9}$ Ibid., pp. 47-48. 
attention of the converted, but also of people of different cultures, races and religions.

From its establishment, Islam in Minangkabau was identical to its Sufistic form. This is apparent, for example, from the popular understanding among the people of Minangkabau concerning the idea of creation. ${ }^{10}$ The question remains, however, what kind of Sufism the people of this region adhered to.

According to Fathurrahman the predominant school of Sufism in Minangkabau was Shattariyah. This order is recorded to have been present here from the return of Shaikh Burhanuddin - leader of Shattariyah order - from Aceh. He studied Tasawuf under the patronage of the famous Shaikh Abdurrauf al-Sinkili. This order has left a marked imprint on the people of this region and guided them to what many have recognized as the tolerant form of Islam. The primary text of this order is Kitab Menerangkan Agama Islam di Minangkabau (A Book on the Explanation of Islam in Minangkabau). ${ }^{11}$

The Shattariyah order was disseminated by Burhanuddin's main disciples into neighboring regions. By the second half of the $18^{\text {th }}$ century, the order had become the sole religious power in Minangkabau. ${ }^{12}$

A unique characteristic of Shattariyah was that it was able to absorb local culture and customs. ${ }^{13}$ From the beginning of the

\footnotetext{
${ }^{10}$ Ibid., p. 45.

11 Oman Fathurrahman, "Tarekat Shattariyah di Dunia Melayu-Indonesia: Kajian atas Dinamika dan Perkembangannya Melalui Naskah-naskah di Sumatera Barat," (Unpublished Ph.D Dissertation, School of Humanity Studies, Postgraduate Program, the University of Indonesia, Jakarta, 2003), p. 164.

12 They include Shaikh Datuk Maruhun Panjang of Padang Ganting Batussangkar, who propagated his teaching in Tanah Datar, Shaikh Tarapang (Syaikh Pandan Baico) of Kubung Tiga Belas Solok, who propagated his ideas in Solok and Sijunjung, Shaikh Abdul Muhsin (Shaikh Supayang) of Supayang, who worked in Alahan Panjang Muara Labuh and Lubuk Gadang, Shaikh Muhammad Nasir (Shaikh Surau Baru) of Koto Tangah Padang, in Koto Tangah Pauh Lubuk Bagalung Padang, Shaikh Buyung Muda (Shaikh Bayang) of Bayang Bandar, in Bandar Sibupuluh and Kuraji, and Shaikh Jalaluddin Kapeh Kapeh of Paninjauan Padang Panjang, in Luhak Agam and Luhak Lima Puluh Kota Payakumbuh. See Ibid., pp. 88-89.

13 See Irina Katkova, "Islamic Manuscripts of Western Sumatera, Problem of Investigation and Preservation (on the Materials Field Research Work in Western Sumatera of 2006)," in http://www.islamicmanuscript.org/resources/files/katkova_Irina_TIMA.pdf/.
} 
conversion of the locals to Islam, efforts had been made to reconcile Islam with the values of local traditions and culture. The Shattariyah order played a constructive role in these efforts. In most cases, the process of reconciliation was gradual. Hence Islam was first introduced into the coastal regions (rantau), and only then into the inland regions (darek, darat). In this strategy lay the conviction that in propagating religion it is wise to proceed gradually from step to step. ${ }^{14}$

Through the Shattariyah order, the process of reconciliation was not only commenced but also intensified. But it was by virtue of the reconciling power of this order that "the Islam" of Minangkabau was and perhaps still is - known for its prudence, tolerance and peaceful manner.

Like those of many others, the traditions and customs of the Minangkabau are complicated. They form a web of complex relationships, drawing together many aspects of human life: social, economic and religious. Furthermore, these traditions contain forces of both conflict and integration. Within them one may find what is commonly called the system of dual laras; Koto Piliang and Bodi Caniago. The former concerns the prestige of leadership, where the leader is considered to be the sole occupying authority at the top of the hierarchy (puncak), whereas the latter concerns the principles of egalitarianism, according to which the country (nagari) must be ruled by a group of religious leaders from various major clans. ${ }^{15}$

Similarly, the social structure of the Minangkabau is just as complicated as its traditions and customs. The social structure consists of two opposing systems, one monarchical, representing patriarchal values, the other a popular system, representing matriarchal norms. In the Minangkabau ethos, this dual system of social structure must at the end be reconciled if society is to survive. Marriage is the way toward that reconciliation because marriage unites two opposing entities man and woman - bringing them together in a spirit of togetherness and harmony. ${ }^{16}$

Following the Islamisation of Minangkabau in the $16^{\text {th }}$ century, the political system in the region changed. A tripartite form of leadership

\footnotetext{
${ }^{14}$ Fathurrahman, “Tarekat Shattariyah,” p. 68.

15 Taufik Abdullah, "Adat and Islam: An Examination of Conflict in Minangkabau," Indonesia 2 (October 1966), pp. 6-7.

16 Ibid., p. 4.
} 
was then introduced according to which the Kingdom was to be ruled by three kings at once. These three kings were the King of Nature (Raja Alam), the King of Tradition (Raja Adat) and the King of Rites (Raja Ibadat), the kings being known in the local language as Rajo Tigo Selo. The King of Tradition - whether man or woman - was seen as the personification of patriarchal values. The King of Rites - again, whether man or woman - was regarded as representing the matriarchal values. Together they were called Rajo Duo Selo and held the prerogative authority in their respective domains. Meanwhile, the King of Nature was expected to combine the two above-mentioned authorities.

In reality, however, there are doubts whether this kind of political system was ever applied in the region, for the heartland of Minangkabau (darat) was in fact never ruled by a king. It was ruled by religious leaders who ran the government hereditarily. The kings ruled only the coastal regions and their territories. ${ }^{17}$

Whatever the case might be, what this paper is interested in is the fact that the concept of the King of Rites was already recognized as part and parcel of the political system in Minangkabau. By any standard, this recognition bears an explicit meaning that the people of Minangkabau had already acknowledged the public role of religion politically and perhaps culturally as well.

Quite apart from this, the concept of nagari (country) also underwent a process of Islamisation. Prior to the advent of Islam, this concept was understood as referring only to the social, political and economic entity. According to this old concept, the nagari was upheld as consisting of a territorial unit comprising agricultural lands, open grounds, parks, sources of water, chicken nesting spots and so on. Legally speaking, the nagari also consisted of certain rules and was associated with certain institutions, traditions or customs. ${ }^{18}$ With the coming of Islam, the nagari was transformed and perhaps modernized to encompass such things as the balai, musajik (mosque), labuah (public road), and tepian tampek mandi (public washing place). Balai was an institution symbolizing the rules of integration and the laws of religion.

\footnotetext{
17 Ibid., pp. 4-5.

18 See John S. Ambler, "Historical Perspectives on Sawah Cultivation and the Political and Economic Context for Irrigation in West Sumatera," Indonesia Vol. 46 (October 1988), p. 42.
} 
The members of this institution, who usually had shown strong religious and intellectual acumen, were called urang patuik.. ${ }^{19}$

The respect that Muslims in general, and the Shattariyah order in particular, showed towards local traditions in Minangkabau opened up the soft ground for the easy process of Islamisation in this region. In the same vein, Muslims, from the advent of Islam, never behaved in a way that would threaten the original foundation of the local community. On the contrary, they helped preserve local culture, strengthen its foundations and enrich its elements. ${ }^{20}$ In this respect, credit must go not only to the Muslims in general but also to the followers of the Shattariyah order who, thanks to their credible understanding of their religion, were able to reconcile Islam with local traditions, and contextualize this religion into the new condition that they found in Minangkabau. It was through this order that Islam was finally and fully integrated into the life of the people of this land.

All this is to say that both the religious traditions and the local customs of Minangkabau were overtly flexible. Both were able to adapt to each other, and absorb one another. By the end of the $18^{\text {th }}$ century, however, Islam was no longer what it was. It was about to change forever. Islam, a religion couched in tolerance and able to understand the very fabric of an alien culture, was now about to be transformed into another kind of Islam at odds with its own values and norms. It was the Naqshabandiyah order that initiated this drastic change. When it came to this region, it sent a shock wave through the whole community, creating early tension and conflict. The source of this conflict was twofold: the inability of the members of this order to respect different religious views, and the political struggle for domination. ${ }^{21}$ When the Padris came in as the patrons of the order, the situation became even worse. Violence in the name of religion prevailed and intimidation became the rule of the day.

\section{The Padris: Their Advent and Development}

Two decades before the end of the $18^{\text {th }}$ century, Minangkabau was known for its gold production. The gold-producing villages in this region and other surrounding villages which acted as export routes

\footnotetext{
19 Abdullah, “Adat and Islam,” p. 12.

20 Ibid., p. 11.

${ }^{21}$ Fathurrahman, “Tarekat Shattariyah,” pp. 164-165.
} 
were supportive of the royal family. However, by the end of that century, the gold trade was in decline, and Minangkabau faced serious commercial problems as a result. By the 1780s Minangkabau had established new commercial centers such as Agam, a cotton producing region outside Tanah Datar, which at the same time was also a trade hub where Javanese salt traders did business with the locals. This new form of trade was quite different from the gold trade in that while the former was open to everyone, the latter was controlled only by the elites. Between the 1790s and 1830s, Minangkabau, especially the regions of Agam and Limapuluh Kota, began to profit from booming coffee demands from countries such as the United States of America. This and other factors helped shift the mode and nature of the power balance within the Minangkabau community. ${ }^{22}$ Economically speaking, men of religion - the clerics and their followers - benefited from this shift and gained higher status accordingly. As the mode of trade shifted from an elite-based trade to an individual-based one, these clerics became the main benefactors because they essentially constituted the major element in the society.

Concomitant to that, this emerging class of clerics, with their power and advantages, brought about a new form of social diversity in the community. Their economic renaissance had notable consequences $^{23}$ for their own political careers and the political opportunities of their followers. All now became major players not only in religious domain but also in economic and political arena.

Following their economic renaissance, Islamic educational institutions such as surau began to flourish. Here numbers of Muslim students converged to study. At the same time these students were also involved in business activities organized by the clerics and their institutions. Hence, there occurred a transformation in society, turning formerly disadvantaged members into an economically advantaged class of new rich. As a result of intensive business activities, these

\footnotetext{
22 See Christine Dobbin, "Economic Change in Minangkabau as a Factor in the Rise of the Padri Movement, 1784-1830," Indonesia, Vol. 23 (April 1977): pp. 1-21.

${ }^{23}$ Helmut Lukas, "The Perception of Indonesia's History and Culture by Western Historian and Social Scientists," (Paper presented at the Conference "Indonesia's Cultural Diversity in Time of Global Change," Indonesian Embassy Brussels, The European Institute for Asia Studies, Brussels, The Royal Academy of Overseas Sciences, Brussels, and The International Institute for Asian Studies (Leiden: 16 December 2002), p. 5.
} 
people soon became wealthy. Since business activities were reasonably lucrative at that time, the number of the rich grew significantly, and the number of people leaving for the Holy Land also increased. This expansion in pilgrimage in itself provides strong evidence that the economy of the people was good. ${ }^{24}$

The visit to the Holy Land turned out to be not only a ritual for these people, but also a process of learning and perhaps indoctrination. They began to hear - and subsequently learn - about the Wahhabipah and its principles. A reasonable number of them even became acquainted with its teachings and sympathetic to its doctrines. Upon their return, they founded a Wahhałiæriented community and disseminated its teachings through out the region.

Among the early Wahhałisin Minangkabau were Haji Miskin of $\mathrm{Lu}(\mathrm{h}) \mathrm{ak}$ Agam, Haji Abdur Rahman of Piobang, a sub-region of Lu(h)ak Limah Puluh Kota, and Haji Muhammad Arief of Sumanik, Batusangkar. Haji Miskin returned from Mecca in either 1803 or 1804 and soon embarked on a reform mission in his homeland. He believed that the structure of the Minangkabau society was not at all in line with the teachings of the Qur'an and the Sunnah, and must therefore be reformed. He sought a replica of the Saudi style of reform where the old structure of society is totally replaced by a new one, regardless of the different nature of the existing social structure. ${ }^{25}$ This idea of total reform was welcomed by a large number of people including Haji Abdur Rahman and Haji Muhammad Arif. In time, the three reached the conclusion that a common platform must be formulated. The situation called for a "holy" mission to commence immediately. The seeds of the Padri movement were sewn, and intellectual agendas to launch what subsequently appeared to be a furious onslaught on their foes were then tabled.

In their effort to undertake radical reform in Minangkabau, the three Hajis received strong opposition especially from the leadership of the Shattariyah order. ${ }^{26}$ Haji Miskin for example, was denounced by Tuanku Nan Tuo, a religious leader and a former business partner of Haji Miskin before the latter left for Mecca. Nan Tuo rejected entirely the ideas of Haji Miskin and succeeded in persuading his followers not

\footnotetext{
${ }^{24}$ Dobbin, "Economic Change in Minangkabau," p. 28.

25 Ibid., p. 30.

${ }^{26}$ Fathurrahman, “Tarekat Shattariyah,” p. 168.
} 
to tolerate those ideas. As a result, Haji Miskin was forced to acknowledge his defeat from his former colleague and left for Enam Kota. He stayed in Pandai Sikat for a while, and continued to propagate his Wahharinspired ideas. But here he failed. He then left for Kota Lawas where - recognizing the causes of his failure - he adopted a new strategy and a more well-planned approach. He succeeded here in promoting his ideas and prompting the total reform to which he aspired. Eventually, he decided to employ a physical approach, burning down public halls (balar) and finally capturing all regions in Enam Kota including Kota Lawas and Pandai Sikat. ${ }^{27}$

While the Padri movement was initially, organized in a rather sporadic and unsystematic manner, as it matured, it developed a more united and centralized form. By the time the Padri movement gained real momentum in 1811, Haji Miskin, with the support from Tuanku Nan Renceh, another religious leader, was already viewed as the strongest leader in the region. Realizing his strength, Haji Miskin officially announced that total reform must by now begin. ${ }^{28}$ He was confident that he would succeed. Apart from the popular support that he received, he was also backed by the so-called Hariman Nan Selapan, eight strong local leaders calling themselves the eight lions: Tuanku of Kubu Sanang, Tuanku of Ladang Lawas, Tuanku of Padang Luar, Tuanku of Galung, Tuanku of Koto Ambalan, and Tuanku of Lubuk Aur. ${ }^{29}$ (only 6 - are they lions or tigers?)

In 1813 Tuanku Lintau signed up. ${ }^{30}$ Some time before that, in 1807, another strong and charismatic religious leader called Tuanku Muda of Alahan Panjang had also joined the group. It was this man, later known as Tuanku Imam Bonjol, who transformed the organization into something else and gave it the real impetus that would move it forward. With his experience and firm leadership, Tuanku Imam Bonjol succeeded in exercising considerable power and

\footnotetext{
${ }^{27}$ Dobbin, "Economic Change in Minangkabau," pp. 30-31.

28 Ibid., p. 32.

${ }^{29}$ See Suryadi, "Kontroversi Kaum Padri: Jika Bukan Karena Tuanku Nan Renceh," in http://naskahkuno.blogspot.com/2007/11/kontroversi-kaum-paderi-jika-bukan.html; Cf. Abdul Qadir Djaelani, "Perang Padri," in http://www.mail-archive.com/urangawak@yahoogroups.com/msg00475.html; Cf. Dobbin, “Tuanku Imam Bondjol,” p. 10 .

30 Dobbin, “Economic Change in Minangkabau," P. 36.
} 
influence over others, and in his hands, the Padri movement turned into a much more solid and well-managed organization.

Under his leadership, the Padri movement expanded its territory beyond Minangkabau to include South Tapanuli and other neighboring regions where the Padris recruited new and fresh leaders such as Tuanko Rao and Tuanku Tambusai.

\section{The Intellectual Fundamentalism of the Padris}

Although some might say otherwise, the Padri movement was, in my view, the reincarnation of Wahhałson in the Arabian Peninsula. It is not hard to find apparent congruencies between the two movements, for instance in their overt attitude and covert propaganda against Tasawuf. The two movements regarded Tasawuf as misleading, and must therefore be banned. The Padris also maintained that the people of Minangkabau, especially the followers of the Shattariyah order were sinful because they committed something not ordained by God in His Sharith. Like the Wahhatis, the Padris were fond of labeling other people bid'ah for practicing certain forms of rituals they were not happy with. Like the Wahhałistoo, the Padris employed physical, often violent means to force people to change their minds, beliefs and traditional customs. ${ }^{31}$

It is quite clear -as many studies have shown- that in their desperate efforts to gain the people's support, the Padris employed a deliberate policy of violence, unfavorable to both society and religion. On these grounds, it is legitimate to argue that this movement was radical outright.

For the Padris, Islam could be understood only as they interpreted it. No other understandings and interpretations were true. It was on this notion that the Padris based all their behavior and conduct. To be more precise, the violent acts of the Padris stemmed from a flawed understanding of Islam. Hence, Tuanku Nan Renceh launched a violent attack against Tuanku Nan Tuo, his own teacher, merely on account of slight differences between them in understanding certain religious issues of no particular importance whatsoever to Islam. Tuanku Nan Renceh went even further by denouncing him and others

${ }^{31}$ Fathurrahman, “Tarekat Shattariyah,” p. 167. 
such as Fakih Saghir as infidels, and nicknaming the latter the "King of the Infidels." 32

Up to this point, one might conclude that the rigid stance of the Padris must have been the result of their method and approach in understanding the texts of Islam. Their method is deeply rooted in a literalistic-textual kind of approach. There might be no apparent danger in this approach. But it led to strange consequences. The Padris, for example, obliged man to grow his beard, or else be fined. They also prohibited men and women from cutting their teeth on pain of being fined one adult cow. A man who walked in public with his legs bared would also be fined a certain amount of money, and so would women who appeared in public without a burka covering her whole body save her eyes and hands. Worse still, a person found neglecting the sqlas(the compulsory five prayers) was to be punished the first time with a fine of 5 gulden, and the second time be condemned him to death. ${ }^{33}$

By virtue of their radical dogma, the Padris not only indoctrinated people but also imposed on their codes of conduct and dress. Thus, the Padris forced people to wear a long white dress as the compulsory form of male dress. ${ }^{34}$ Those who disobeyed this order would be punished. The Padris called themselves "the whites" and were required always to appear in that colour.

In addition to these rather absurd rules and regulations, the Padris also formulated religion-based laws that, at first sight, look contradictory. For instance Tuanku Imam Bonjol, the highest authority in the movement, while ruling that slavery was prohibited, himself owned many slaves. He sometimes also announced publicly that slavery was permissible. In his memoir, written by his own hand, Tuanku recorded that he had 70 slaves man and women. ${ }^{35}$ This is an apparent contradiction indeed, and is against the very teaching of Islam. Islam speaks of freedom, equality and justice for all people whatever their race, language, color or religion. The whole mission of

\footnotetext{
32 Suryadi, "Kontroversi Kaum Padri."

${ }^{33}$ Fathurrahman, "Tarekat Shattariyah,” p. 167.

34 See Dobbin “Tuanku Imam Bondjol,” p. 10; Cf. Mangaraja Onggang Parlindungan, Pongkinangolngolan Sinambela Gelar Tuanku Rao: Teror Agama Islam Maz̧hab Hambali di Tanah Batak. 1816-1833 (Yogyakarta: LKiS, 2007), p. 132.

35 See “Memorandum of Tuanku Imam,” pp. 19-20.
} 
the Qur'an and Muhammad's prophecy is to abolish slavery, and to establish justice and equality.

Slavery in Minangkabau has its roots in the period prior to the coming of Islam. Slaves were considered the second-class citizens. After the coming of Islam, the system of slavery was only applied to non-Muslims. These slaves normally originated from such regions as Nias, Mentawai, Tapanuli and Riau, and a large number of them resided in remote parts of the nagari, quite isolated from the majority of the people. In most part, they were employed as laborers in agricultural sectors or as domestic workers, and by virtue of their being slaves, they could not get married to someone who was not slave. In certain phases of Minangkabau history, efforts were made to free these slaves, but these efforts came to no fruition and slavery was even regaining its momentum at the time of the coming of the Padris. ${ }^{36}$ Ironically, however, while the Padris spoke of the application of Sharith, they themselves, at the same time, violated the benevolent values of Islam and advocated instead the abhorrent self-made rules and regulations of the slavery system.

The literalistic nature of their approach toward the Qur'an and the Sunnah seems to have made them unable to look beyond the literal meaning of the two major sources of Islam $\cdot{ }^{37}$ Hence, they ignored the concept of Rahilar $>$ according to which a rule must be underpinned by the spirit of compassion and forgiveness. The Padris failed to do this, and in their appeal to apply the rules of Sharish, they forgot that the heart of Sharith is compassion, respect, tolerance and justice. They also failed to respect other views and opinions on Islam and tended to go overboard when damning their foes as infidels and hypocrites.

When a literalistic approach is applied, as El Fadl has noted, one is forced to read a religious text in isolation from the historical and moral context. In this method of interpretation, the substantive content of the text may often be ignored. The result is a rigid, one-sided and inauthentic interpretation of Islam. ${ }^{38}$ This indeed was both the style

\footnotetext{
36 Graves, Asal Usul Elite Minangkabau Modern, pp. 29-31.

37 See Fazlur Rahman, Islam and Modernity: Transformation of an Intellectual Tradition (Chicago and London: The University of Chicago Press, 1982), p. 4.

38 Khaled Abou El Fadl, "Toleransi dalam Islam," in Joshua Cohen and Ian Lague (eds), Cita dan Fakta Toleransi Islam: Puritanisme versus Pluralisme, Translation (Bandung: Arasy Mizan, 2003), p. 31.
} 
and attitude of the Padris in their interpretation on the Qur'an and the Sunnah, a style that gave birth to their rigid and absurd understanding of this noble religion.

In practical terms what this implied was that the Padris then tended to legitimize their acts and justify them on religious grounds, regardless of whether or not these acts were against moral norms and religious values. The Padris were unequivocally fundamentalist in the literal sense of the word.

The connotative and pejorative meaning of the word fundamentalism is still open to debate. It was first used to refer to the radical Protestant group in America in the beginning of the $20^{\text {th }}$ century. Members of this group called themselves fundamentalists to distinguish them from liberal Protestants, whom they regarded as having been misled from the true faith of the religion. The Protestant fundamentalists, like the Wahharis and the Padris, employed a literalistic approach to their understanding of the teaching and tradition of their holy texts. ${ }^{39}$

On many accounts, fundamentalism is peculiar, but not unique, to Christianity. Armstrong, following Martin E Marty and R. Scott Appleby, maintains that fundamentalism is a form of militant spiritualism vis-à-vis what is considered to be a moral crisis. Fundamentalism is a response toward the beliefs, and perhaps prejudices, of the secularists. In their attitude towards secular thought, the fundamentalists argue that the struggle to reveal its inherent lack of balance represents a cosmic war against evil. It should come as no surprise that in their bid to wage their war, fundamentalists first and foremost tend to resort to the strictest dogma of their religion as a way to preserve their faith against the perceived onslaught of the secularists. Dubbing themselves the only true representatives of their religion, fundamentalists of any religious tradition normally live an isolated life away from society and create their own community and culture. ${ }^{40}$

In the same vein, Azra, modifying the thesis of Marty and Appleby, argues that a constant characteristic of fundamentalism is resistance against modernity, secularism, Western values, the methods

\footnotetext{
39 See Karen Armstrong, The Battle for God: Fundamentalism in Judaism, Christianity and Islam (London: HarperCollins Publishers, 2000), p. x.

40 Ibid., p. xi.
} 
of hermeneutics, pluralism, relativism (cultural and not religious relativism) and a rejection of the social and historical dynamism which fundamentalists deem to represent a threat toward religion. ${ }^{41}$ For Habermas, on the other hand, the main characteristic of fundamentalism is rigidity and stubbornness in imposing, politically and onesidedly, its values and convictions upon others, in order to disguise the fact that these values and convictions are irrational. ${ }^{42}$

While there are subtle differences in these accounts concerning fundamentalism, these propositions nonetheless agree that fundamentalism, in a broad sense, is a form of rigid religiosity that calls for the direct return to the original sources of religion by means of violence and force.

In the history of Islam, fundamentalism in the sense of returning to the original sources of religion and of interpreting these sources literally has been known since the early phase of its development. As such, it was first witnessed during the Tahbira (peace deal) between Ali and Mu'ariyah, when a third party, the Khawarij, declined to get involved in it. This third group turned violent and quickly pointed fingers at both Ali and Mu'ariyah as infidels. In the view of the Khawaid, the two had committed a grave sin by agreeing on arbitrage which was in its nature against the very teaching of the holy texts. The two must therefore be killed.

In Islam, fundamentalism confronts not only modernity but also its own tradition and legacy. Muslim fundamentalists are trapped in their own obsession as if they are beaten, isolated and marginalized not only by the lucrative power of modernity but also by the wellpreserved traditions of Islam. ${ }^{43}$ It seems Muslim fundamentalists were first frustrated by the traditions of Islam, and only second were marginalized by the lore of modernity.

On these grounds, one may speak of two forms of fundamentalism in Islam. One is classical fundamentalism, and the other is neofundamentalism. The Padri movement is close to the former. Since its

\footnotetext{
${ }^{41}$ Azyumardi Azra, Pergolakan Politik Islam: Dari Fundamentalisme, Modernisme bingga PostModernisme (Jakarta: Penerbit Paramadina, 1996), pp. 109-110.

42 Giovanna Borradori, Filsafat dalam Masa Teror: Dialog dengan Jürgen Habermas dan Jacques Derida, Translation (Jakarta: Penerbit Buku Kompas, 2005), pp. 45-46.

${ }^{43}$ Khaled Abou El Fadl, "Islam and Theology of Power," in Middle East Report, 221, (2001), from http://www.merip.org/mer/mer221/221-abu_el_fadl.html.
} 
very inception, the proponents of this movement propagate the idea of the direct return to the Qur'an and to the purest form of Islam, that is, to the original form Islam revealed to the prophet Muhammad. Thus, the Padris did not acknowledge medieval Islam as representing the idealistic Islam. They also renounced the modern reality of Islam as not symbolizing the pure form of this religion. The Padris were obsessed by a pure form of Islam, the prophetic Islam as exemplified in the life of the Prophet Muhammad and in his four exemplary disciples. Peculiar to the Padris is furthermore their insistence on the truth-claim, that what was true was what they thought to be true. Truth became their commodity.

It goes without saying, therefore, that the Padris,were incapable of distinguishing between Islam as ordained in the Qur'an and the Sunnah and Islam as the product of man's discursive interpretation. The former is absolute while the latter may become obsolete over time. The grave mistake of the Padris lay in their assumption that the obsolete interpretation of Islam might represent, and perhaps replace, the absolute aspect. The truth is that the interpretation of Islam is subject to change and criticism, open to objection and re-interpretation, while the absolute aspect of Islam will stay as it is. In the final analysis, the Padris were by all standards absolutists who believed that criticism of them was an attack against Islam itself.

\section{The Radicalism of the Padris}

The radicalism of the Padris may be found in two domains, first in their discursive interpretation of Islam, and second in their day-to-day attitude towards others.

Violence was the rule of the day for the Padris. This violence, to borrow from Galtung, took three forms: structural, occasional and cultural violence. Whereas the first two involved physical and direct violence against opposing parties, the third concerned the process of legitimization and justification of violence itself.

The data at my disposal reveal that the Padris committed cultural violence by justifying what they did by means of religion, ideology, language and knowledge. They condemned their opponents as infidels by citing verses of the Qur'an and prophetic sayings. They systematically designed structural violence by marginalizing their opponents among individuals and groups of Minangkabau. This structural violence was then followed by occasional violence in the form of physical attacks, abduction and even assassination. All this was 
justified by religion as if religion was responsible for these abhorrent acts.

One of the violent acts that the Padris committed was the assassination of the royal family of Pagaruyung, Tanah Datar. This royal family converted to Islam in the $16^{\text {th }}$ century and was attacked by the Padris in 1809. Puti Reno Raudha Thaib assumes that the tragic assassination happened when the Padris and representatives of certain traditional tribes were involved in an argument on matters of particular religious importance. In that argument, Tuanku Lelo of South Tapanuli, one of the Padri most ambitious leaders alleged that some members of royal family such as Tuanku Rajo Naro, Tuanku of Talang and another prince, were abandoning the tenets of Islam. They had become infidels, and must therefore be killed. ${ }^{44}$ The Padris were then provoked and ran amok, murdering all in their way, including the leading members of the royal family, one of the king's assistants, and some royal clerics. ${ }^{45}$

Several years later, in 1815, the Padris led by Tuanku Lintau initiated another attack on the royal family. They murdered all its living members. ${ }^{46}$ Some historians relate that the Kingdom of Pagaruyung experienced attacks from the Padris on many occasions, as a result of which it finally collapsed.

The Padris also intimidated their opponents and anyone who stood in their way including their own family members. Adrianus Khatib, a researcher, following Steijn Parve, believes that Tuanku Nan Renceh was responsible for the suffering of the elderly woman who happened to be his own aunt. When the poor woman died, he decreed that the body should not be properly buried, but be thrown away in the bushes. The lady was killed by the Padris simply because she ate

44 This includes a paper by A.A. Navis, Alam Terkembang Jadi Guru (Jakarta: PT Pustaka Grafiti Press, 1984); MD Mansur et. al., Sejarah Minangkabau, (Jakarta: Bharata, 1970); and Muhamad Radjab, Perang Paderi (Jakarta: Balai Pustaka, 1964).

${ }^{45}$ See Puti Reno Raudha Thaib, "Sejarah Istana Pagaruyung," in http://groups.yahoo.com/group/RantauNet/message/61114.

46 See Dobbin, "Economic Change in Minangkabau," pp. 36-37; Cf. M.C. Ricklefs, "Islamizing Indonesia: Religion and Politics in Singapore's Giant Neighbour," public lecture Asian Civilisations Museum, Asia Research Institute, National University of Singapore (23 September, 2004), p. 1. 
sirib leaves, something forbidden according Padri law. ${ }^{47}$ Ironically, however, this act-the murder by Tuanku Nan Renceh of his own aunt-was condoned by other members of the movement and was even applauded by the most fanatical.

The above passages on the violence committed by the Padris and the civil wars they instigated may paint a picture of instability and never-ending chaos in Minangkabau. What was to follow was even worse. For it was this condition of instability that triggered the eventual coming of the Dutch to the land of Minangkabau. It may seem shameful but at the same time it is understandable, that some traditional tribal leaders and the royal family of Pagaruyung, in their attempts to defend themselves against the Padris, appealed to the Dutch for help. It was Sultan Muningsah of Pagaruyung who first invited the Dutch to come to Minangkabau. Agreement between the two parties soon followed. On the $21^{\text {st }}$ February 1821, the traditional tribes of Minangkabau agreed to grant the Dutch the whole region of Lu(h)ak Nan Tigo (Agam, Tanah Datar and Lima Puluh Kota) on the condition that the Dutch protect them from the onslaught of the Padris. In April of the same year, the Dutch attacked Simawang and Sulit Air, and quickly controlled them after some little resistance from the Padris. ${ }^{48}$ Meanwhile, without request from the appealing tribes and royal family, the Dutch, on their own initiative expanded their domination over Tanah Datar and other surrounding areas.

Soon after controlling Tanah Datar, the Dutch built a fortress in Batusangkar near the Pagaruyung palace from which they launched frantic attacks against the regions of Padang Lawas and Pandai Sikat in Agam. Here the Dutch built another castle, which subsequently became their stronghold in successive attacks on the region of Kota Baru. In this region, the Dutch encountered strong resistance from the Padris, even suffering defeat such as in the battle of Kapau, and they were forced to withdraw. In 1831, the Dutch, under the leadership of Colonel Elout, returned to Kapau and succeeded in capturing it. The colonizing power soon expanded its dominion and quickly controlled

47 Adrianus Khatib, "Kaum Padri dan Pemikiran Keagamaan di Minangkabau," (Unpublished Ph.D Dissertation, Postgraduate Program, IAIN Syarif Hidayatullah, Jakarta, 1991), p. 269.

48 Suryadi, “Tuanku Imam Bonjol: Dikenang Sekaligus Digugat,” in http://naskah kuno.blogspot.com/2007/11/tuanku-imam-bonjol-dikenang-sekaligus.html. 
Alahan Panjang and Bonjol.49 Finally, the Dutch dominated Minangkabau, the last and the most important stronghold of the Padris.

During the many years of the Dutch war with the Padris many peace deals, including cease-fire agreements, were signed by both parties. However, as soon as a peace deal was signed, both parties tended to return to war and attack each other. For instance, General de Stuers, chief commander of the Dutch military force in Padang, and Imam Bonjol signed a peace deal in 1824, but soon ruined the deal, violated it and took up arms again. In most cases, it was the Padris that initiated the attacks and committed anarchical acts against the Dutch. The Dutch generally acted only in self-defense. ${ }^{50}$

In the meantime, the Padris had their own version of this whole issue. They maintained that it was the Dutch who violated the peace deals, initiated the attacks and embarked on incursions against the Padris. The Naskah Tuanku Imam Bonjol relates that when the two parties reached a peace deal, Colonel Elout, the successor of General Stuers, promised in 1831 that he would not interfere with the social and religious affairs of the local people. ${ }^{51}$ In reality, however, when the Dutch occupied the region of Banjul, they, according to the Naskab, entered a mosque and broke into people's residences bringing with them dogs and other filthy materials. They also confiscated people's belongings, compelled them to do hard labor and plundered their rice fields without compensation. The Naskah further mentions that the Dutch torched the local communities, often without any acceptable reason. ${ }^{52}$

Be that as it may, whether it was the Dutch or the Padris that should be held accountable for these atrocities, countless testimonies have it that the Padris, amid social and political unrest in Minangkabau and while the people were suffering from the continuing war in the region, who kept on committing harassment against the hopeless. They also expanded their propagation to penetrate Mandailing, a region to the north of Minangkabau in 1820, and "forced" the local people to

\footnotetext{
49 "Memorandum of Tuanku Imam," pp. 21-23.

50 See Graves, Asal Usul Elite Minangkabau Modern, p. 68.

51 “Memorandum of Tuanku Imam," p. 24.

52 Ibid., p. 27.
} 
embrace Islam..$^{53}$ Here in Mandailing, the Padris again harassed the people and tortured them in the same way that they did in Minangkabau when they, under the leadership of Tuanku Tambusai and Tuanku Rao, terrorized the people with all sorts of threats and intimidation.

In their attacks against their victims, the Padris often sought assistance from the Bataks, who themselves originated mostly from Mandailing. ${ }^{54}$ In this way the Padris divided the people in order to rule them.

In Mandailing people were forced to defend themselves, and eventually they launched an armed struggle against the Padris, recruiting in the process people from all walks of life including pagans, Muslims, non-Muslims, immigrants and indigenous people. The latter were known as Lubus, and their leaders were Patuan Naga and Raja Gadombang. These two leaders tried to stand firm in their self-defense against the Padris, but without a great deal of success, and after consecutive failures, they sought military assistance from the Dutch in 1832.55 The Dutch cooperated with the indigenous people and together they launched an attack on the Padris and gained an easy victory as a result.

Violence by the Padris in Mandailing has been the subject of many studies. Harahap, following Willer, narrates that, in their efforts to intimidate their victims, the Padris surrounded their villages and threatened them with swords, burned down their houses and stole their belongings. They also commandeered people's domestic animals and even murdered those whom they considered a danger to them. Those who survived the murder attempts during the raids were enslaved. ${ }^{56}$

That is one view. Some scholars hold an opposing view and question whether the Padris were really that violent. These scholars doubt the authenticity of evidence for the hideous acts of the Padris. Lukas for example, believes that most of the information that stands

\footnotetext{
53 Abdur-Razzaq Lubis, "Mandailing Islam Across Borders," Taiwan Journal of Southeast Asian Studies, Vol. 2, No. 2 (2005), p. 60.

54 Ibid., p. 61.

55 Ibid., p. 63.

56 See Basyral Hamidy Harahap, Ggeret Tuanku Rao (Depok: Komunitas Bambu, 2007), p. 63.
} 
against the Padris is Dutch-based, and must therefore be questioned and investigated. He further warns that acts the Dutch committed against the Padris in particular and the people of Minangkabau in general resemble what Bush has done toward al-Qaeda and the Muslims at large. ${ }^{57}$ What Lukas and people like him try to say is that, as far as the historical information is concerned, the Dutch attempted to distort history, putting blames on the Padris and destroying the image of the Muslim in general.

What Lukas questions then is the authenticity of the data. And Lukas is not alone. Hamka shares his skepticism, questioning the data presented by MO Parlindungan in his Tuanko Rao. To Hamka, this book lacks accuracy because it does not include in its pages solid and clear data. However, upon closer inspection, Hamka himself does in fact acknowledge that the Padris committed violence on many occasions. He quotes Hikayat Shaikh Jalaluddin of Faqih Shagir and remarks that:

"... what is evil about the Padris is that they murdered clerics and scholars, raped married women, married women without their consent, committed fornication against prisoners of war, humiliated men of honor, and alleged that their opponents were infidels..." 58

Shagir, for his part, reports that when Tuanku Nan Renceh and his troops attacked the nagari Tilatang, they demolished its buildings and houses, pulled down public facilities, and robbed people's belongings and their animals. Those who survived the assault had to run away and take refuge in another region. ${ }^{59}$ It is narrated also in Naskah Tuanku Imam Bonjol, that Tuanku Imam Bonjol also acknowledged that during his leadership he and many of his colleagues and subordinates committed all sorts of violence including human trafficking and slavery. ${ }^{60}$

\footnotetext{
${ }^{57}$ Helmut Lukas, “The Perception of Indonesia's History and Culture,” p. 4.

58 See "Mengenang Sanggahan Hamka," Tempo, 34/XXXVI (15-21 October 2007).

59 The text reads: "Maka sampailah habis nagari Tilatang dan banyaklab [orang] berpindah dalam nagari; dan sukar menghinggakan ribu laksa rampasan, dan orang terbunub dan tertawan lalu kepada terjual, dan [wanita] dijadikannya gundi'nya [gundiknya]." See Suryadi, "Kontroversi Kaum Padri."

${ }^{60}$ Harahap, Ggeret Tuanku Rao, p. 104.
} 
The data that I acquired from Shagir and the Naskah further reveal that the Padris used violence not only as a means of intimidation and victimization but also as an effective strategy to propagate their ideas and reform mission. There can be no doubt therefore that the Padris may be called radical on that point.

One should be objective in looking at historical data. The Padris were radical, just as the Dutch were colonialist. Both committed atrocities equally against the innocent people of Minangkabau and represent the same form of radicalism by using religion and economic ambition respectively. Both victimized the local people and reduced them to a state of mental disorder.

In view of this, the information provided by Parlindungan concerning the background of the Padri movement and its leadership cannot be overlooked. As he has discovered, Haji Piobang, one of the Padri leaders, was a retired colonel who used to work for Janiseri Kavaleri, a Turkish military unit. Similarly, Haji Sumanik, another Padri leader was a retired major who also used to work for another Turkish military unit. The two were not learned, and were purely military men. ${ }^{61}$ Looking at their background, it seems highly likely that the style of the Padri leadership was predominantly militaristic using torture and violence to persuade people and subdue them.

\section{The Padri Radicalism: Between Religiosity and the Politics of Domination}

The militaristic style of the Padri leadership, its thought and agendas all suggest that this movement was an extension of the Wahabi ideology in Saudi Arabia. Like the Wahhał; $>$ the Padri movement was first of all concerned with the purification of Islamic teachings. But given the geographical and social milieu, the Padri movement had some internal uniqueness not exhibited by the Wahhał> group. In other words, while there were some striking similarities between the two movements, there were also some noticeable differences between them. They were the products of different geographical, cultural and social circumstances.

Nonetheless, regarding their militancy and political mission, they seem to have been the same. They also shared the quality of absorbing the doctrines of their leaders and transforming those doctrines into

${ }^{61}$ See Parlindungan, Pongkinangolngolan Sinambela Gelar Tuanku Rao, p. 126. 
practical agendas. The two movements were both conscious that in order to succeed in their cause, there had to be a process of indoctrination, which would normally start from the idea that a return to the pure teaching of the Qur'an and the Sunnah was a must. This would then be followed by the creation of a so-called "Islamic identity"; an identity which would mostly be identifiable through dress, attitude, and a certain way of thinking. In their efforts to establish their dream community, the Wahhałiand Padri movements invented this new identity to distinguish themselves from others.

To this it may be added that the attempt by the Padris in particular to invent the new identity was in fact a perfect testimony to their political, social and missionary failure. The Padris, it is noted by some historians, were generally not welcomed by the societies in which they operated. To express their frustration at not gaining recognition from their community, they then invented a new community with a new identity. ${ }^{62}$

The invention of this new community may also be a sign that the Padris were not happy with the hereditary system of their nagari. According to this system, people of no social status could not become the staff, let alone the elite, of the nagari. By and large the Padris came from the non-elite, so, having realized that they could not hold certain governmental posts at the nagari by virtue of their social status, they revolted and invented a community of their own. ${ }^{63}$

Whatever the case might be, all the above evidence indicates that the Padris, in the pursuit of their cause, seemed to have employed violence and intimidation. Another point to note is that, what the Padris really wanted was power, and they did not hesitate to employ violence as the swiftest means to acquire that power. They also seemed to have realized that violence might serve as a vehicle to achieve internal and collective solidarity among their members.

What is curious about the Padris is the fact that they attempted to centralize their power at the hands of certain individuals only. These individuals had to possess certain religious qualities such as good leadership, and being learned and well-versed in religious knowledge. The danger of this strategy was that when violence was perpetrated, it was committed symbolically in the name of religion, because the

\footnotetext{
62 See Abdullah, “Adat and Islam,” p. 14.

${ }^{63}$ See Graves, Asal Usul Elite Minangkabau Modern, p. 50.
} 
leaders were men of religion, and was committed collectively because the power was politically centralized.

Strangely enough, the Padris had a certain amount of success in gaining support from the masses. The religious sentiment that the movement was attached to helped it persuade people of "good religiosity" to follow its cause. Like other radical movements, the Padri successfully built a communal loyalty that would later serve as the very ground for its ideological foundation. Moreover, the loyalty that the Padris built was not based on customary traditions or social norms, but on religion and faith. ${ }^{64}$ In other words, it was religion, not local traditions, that counted.

On these grounds, whatever the Padris did in violating certain rules or in intimidating people, they justified by the norms of their religion. This, in turn, irrevocably prompted further acts of violence in the name of religiosity.

Bearing all this in mind, there can be no doubt that the Padri movement was fundamentalist or radical in nature. In these final passages, I would like to touch briefly on the meaning of fundamentalism and radicalism. I follow Olivier Roy in arguing that there is slight difference between the two, in that fundamentalism becomes radicalism when the fundamentalists' dreams of realizing their objective is transformed into a practical agenda. ${ }^{65}$ The fantasy of the fundamentalists consists mostly of acquiring of power using religious sentiment. I would also like to add that these two concepts radicalism and fundamentalism - do seem to be related. In my view, radicalism develops out of the womb of fundamentalism. Political and social conflict is the result of fundamentalism, but the act of being anarchical in this conflict is called radicalism.

Moving to the discursive domain, radicalism and fundamentalism tend to be the product of the same mentality. In general, both radicals and fundamentalists are people of superficial understanding of their religion, developing a correspondingly short-sighted view concerning the religion itself, society and democracy. ${ }^{66}$ This superficial

\footnotetext{
64 Ibid., p. 49.

65 Olivier Roy, Genealogi Islam Radikal, Translation (Yogyakarta: Genta Press, 2005), pp. 13-14.

${ }^{66}$ See Muhammad bin 'Alawi al-Maliki, "al-Ghuluwwu wa A A Ifsal-Mujtama',"'a compilation of papers of the National Seminar Nasional on al-
} 
understanding of religion is the result of a methodological shortcoming according to which a particular religion is deemed truer than another, or one society is thought to be better than another. This kind of methodology is called 'scriptural' or 'literalistic', and often, to say the least, ignores the historical and social context in interpreting religious texts. Text is always true in what it says without any consideration of the social, cultural and historical background of a society. Social and historical contexts are assumed dead. The text is understood in isolation of these contexts.

Having shed light on the methodological mode of the Padris, I may repeat that, in this respect, the Padris share a lot with the Wahharis The only slight difference - discontinuity, borrowing Foucault ${ }^{67}$ - lies in the social and cultural backgrounds out of which they were born. This difference in social and cultural backgrounds does give rise to different traits in terms of propagation strategy or in organizational structure. Hence, the Wahhałs; for instance, in their strategy to counter the attacks of the Ottoman Empire, recruited members of various tribes around the Saudi Peninsula. But the Padris never did the same. They, on the contrary, distanced themselves from the tribes and regarded these tribes as their enemies that must be banished. The Padri strategy, in this particular instance, led to war, conflict and discord, while the Wahhasistrategy produced peace and accord.

The Padris were also selective when drawing their religious tenets from Wahhałidogmas. While, in certain areas, the Padris adopted Wahha 2 loctrines wholeheartedly, in others, they did not. The Padris sometimes also combined Wahha Thus, according to the Naskah Tuanku Imam Bonjol, as cited by Dobbin, the Padris, in their accounts of the twenty attributes of God, ${ }^{68}$ adopted the view of the Asharyah and combined it with the doctrine of the Wahharipah. What the Padris intended to do in these instances was to persuade people that their views were sound and justifiable because

Ghuluwnu wa al-I'tida Ru'yah Manha) Shabalah (Makkah al-Mukarramah, 5-9 Dhu al-Qa'dah $1424 \mathrm{H})$, pp. 36-37.

${ }^{67}$ See Michel Foucault, "Nietzsche, Genealogy, History," in D. F. Bouchard (ed.), Language, Counter-Memory Practice: Selected Essays and Interviews (Ithaca: Cornell University Press, 1977), p. 154.

${ }^{68}$ Dobbin “Tuanku Imam Bondjol,” p. 13. 
they were based not only on Wahharipal but also on the authoritative Ash'aryah school of thought.

Ultimately it is clear that the Padris aimed at politicizing Islam and its teachings by using the doctrines of Wahharipah and Ash'aryah. When these doctrines were formulated in political terms, a tendency toward acquiring power and domination became even more apparent. Religion was ideologicized, the purpose of this ideologicization being none other than power, domination and authority.

The differences that the two movements have were social, political and cultural, as well as economic. Some argue that economic factors actually gave rise to the emergence of the Padri movement, other factors being merely to the economic factor. When they planned certain agendas, the Padris often had an economic purpose in mind. Thus, when they invaded the region of Tanah Datar, they first captured areas with rich natural resources and ignored the others. ${ }^{69}$ Similarly, when they expanded to the north, they took as their bounty agricultural products such as rice, corns, sugarcane, and the like. Gusti Asnan, a historian, testifies in weekly Tempo magazine that when the Padris were forced to surrender to the Dutch in the south, they fled to Pasaman and Tapanuli, two rich regions with diverse natural resources. They moved there first of all because of the regions' rich and fertile land. It produced mainly coffee.

That the Padris were in need of money was understandable. They needed to fund their propagation as well as their war against other tribes, foes and above all the Dutch. ${ }^{70}$

To speak of the radicalism of the Padris one does need to consult the view of Taufik Abdullah, an authoritative historian in modern Indonesia. $\mathrm{He}$, as Lucius cites, maintains that in their radicalism the Padris were driven not only by religious ideals, but also by economic and political obsessions..$^{71}$

Bassam Tibi, in his thesis concerning religious fundamentalism, argues that in their determination to grab cultural, economic, social and political ends the fundamentalists tend to manipulate and distort

\footnotetext{
${ }^{69}$ Dobbin, "Economic Change in Minangkabau," p. 37.

70 “Kontroversi Kebrutalan Kaum Padri," Tempo, 34/XXXVI (15-21 October 2007).

71 Robert E. Lucius, “A House Divided: The Decline and Fall of Masyumi (19501956)," (Unpubslihed MA Thesis, the Naval Postgraduate School California, September 2003), p. 23.
} 
religious symbols. ${ }^{72}$ Al-Jabiri argues along the same lines. In his view, radicalism cannot be looked at simply as social and historical phenomenon, but also as a religious problem. ${ }^{73}$

Bearing in mind these accounts, it is safe then to assume that religious fundamentalism is a form of politicization of religion. It reduces religion to a mere political practice. This holds true for all fundamentalist groups. With a slight difference in degree all fundamentalist groups use religion as their vehicle and distort its teachings for political interests.

That the Padris, in their manipulation of religion, ended up in violence is clear. What is not clear is whether they themselves realized that they had manipulated religion and committed violence along with the process of manipulation. Interestingly, it is narrated in Naskah Tuanku Imam Bonjol, (as cited by Harahap) that Tuanku Imam Bonjol did realize that. He once issued an order to his followers to give back the bounty they had grabbed in the regions of Bonjol and Lubuk Sikaping to the original owners. ${ }^{74}$ In another part of the Naskab (as cited by Dobbin) he was said to have told his son Su(l)tan Caniago, in the minutes before his surrender to the Dutch, to honor and obey religious and customary leaders, and learn the Islamic science concerning the twenty attributes of God. ${ }^{75}$ The assumption behind this narration implies that Tuanku Imam Bonjol seems to have repented from his horrendous acts and did not want his followers and son to do the same.

Nonetheless, what Tuanku Imam Bonjol did does not reflect the policy and mentality of all Padri members. The fact remains that the Padris did continue to commit violence especially under the leadership of Tuanku Tambusai.

History reveals that the Padris never succeeded in disseminating their radical views and agendas. By 1833, the people of Minangkabau had already realized that the dull radicalism of the Padris with its catastrophic impact must be brought to an end. A group of people

\footnotetext{
72 Bassam Tibi, The Challenge of Fundamentalism: Political Islam and the New World Disorder, (Berkeley - Los Angeles - London: University of California Press, 1998), p. 23.

${ }^{73}$ See Muhammad 'Abid al-Jabiri, Qaddraral-Fikr al-'Arabi $\rightarrow a l-M a s$ 'alah al-Thaqa) (Beirut: Markaz Dirasah al-Wahłah al-'Arabiyyah, 1994), pp. 134-135.

${ }^{74}$ Harahap, Ggeret Tuanku Rao, p. 94.

75 Dobbin “Tuanku Imam Bondjol,” pp. 12-13.
} 
therefore initiated a public meeting involving the Padris, the tribal leaders and community members. They proposed that reconciliation must be achieved, and that all elements of the people of Minangkabau should rather join forces to combat the Dutch. This effort came to no fruition, and the Padris walked out. In their stubbornness, they declined to reconcile with the tribal leaders and other community members, and chose instead to go their own way in pursuing their obsessions.

The lesson behind this initiative is that, while the radical nature of the Padri movement in Minangkabau was clear, a larger part of this community remained moderate and polite. They respected tolerance and pluralism. They were the patrons of peace and harmony. They seem to have realized that society could not be built upon conflict and discord. Society must be built upon understanding, respect and accord. Accord, and not discord, was the key. Peace was a precious good. Where violence predominated, the whole society would suffer. When war struck, peace would be a piece of history.

\section{Conclusion}

History will never repeat itself. Tragedy has its own space and time. The tragedy and atrocity of the Padris were not the same as the tragedy and atrocity of the Wahharis. Each movement had its own history and fate. What can be said of the Padris cannot be said of the Wahha 8 s and vice versa. Nonetheless, these two movements share similarities. Both, for example, were radical in their determination to establish what they thought of as pure Islamic values. In addition, both were manipulative of religious symbols in pursuit of their political agendas.

The complexity that reveals itself in investigating such radical groups as the Padri and Wahharimovements stands as the paramount testimony that groups such as these deserve to be studied. Within such study lies a concern to expose the notion of continuity -and also discontinuity- between religion and politics, and the relation between religion and state.

However, it is naïve, to say, for example, that the Padri movement represented Islamic values and Muslim idealism as a whole. It is even naïve to say that the Padri movement was always about radicalism for there are accounts which say otherwise. The Padri movement was one thing and Islam is quite another. Moreover, each radical movement has its own space and time. What a radical movement did in a particular 
space and time cannot be said as representing other movements or persons of entirely different space and time.

Nonetheless, one cannot be silent in the face of radicalism. Over time, the lore of radicalism has brought catastrophic atrocities against humanity. One needs to be cognizant therefore of the peril of radicalism, or else other people may be its next victims. Radicalism equals to death. Once violence reigns, death follows. By virtue of radicalism innocent people can be physically, mentally and physiologically victimized. They may lose their future, their loved ones, belongings, wealth and even life.

On the other hand, the history of humanity has shown that violence cannot be dealt with by violence. Vis-à-vis violence one must abstain from violence. One must maintain public order and observe moral virtues. Those who claim to be religious must try to understand the message of their religion in moral and spiritual terms so that the moral message embodied in all religions may be revealed. All religions are morally and spiritually appealing. So, it is appalling to see that one cannot learn from the moral and spiritual message of religion.

To free religion from the cage of politics is, therefore, necessary. Religion must be treated properly and proportionally as a source of morality. Failing to do this would have the unfortunate consequence of banishing religion from its public role. As a source of morality, religion is capable of bringing peace and harmony, enabling people of whatever race, culture, language, ethnicity and even religion to sit together and achieve common goals. Religion is the inspiration for justice-seekers with its noticeable concept of equality, respect and tolerance. []

\section{Bibliography}

\section{Books and Articles}

Abdullah, Taufik. "Adat and Islam: An Examination of Conflict in Minangkabau." Indonesia, Vol. 2, October, 1966.

Ambler, John S. "Historical Perspectives on Sawah Cultivation and the Political and Economic Context for Irrigation in West Sumatra." Indonesia, Vol. 46, October, 1988.

Armstrong, Karen. The Battle for God: Fundamentalism in Judaism, Christianity and Islam. London: HarperCollins Publishers, 2000. 
Azra, Azyumardi. "Islamic Radical Movement in Indonesia." Paper presented at the Conference "The Link-up Terrorism in Southeast Asia," Center for Moderate Muslim, Jakarta, 2006.

-. Jaringan Ulama Timur Tengah dan Kepulauan Nusantara Abad XVII dan XVIII. Bandung: Mizan, 1994.

-------. Pergolakan Politik Islam: Dari Fundamentalisme, Modernisme hingga Post-Modernisme. Jakarta: Paramadina, 1996.

Benda, Harry J. The Crescent and the Rising Sun: Indonesian Islam under The Japanese Occupation 1942-1945. Netherlands: W. van Hoeve Ltd. The Hague and Bandung, 1958.

Borradori, Giovanna. Filsafat dalam Masa Teror: Dialog dengan Jürgen Habermas dan Jacques Derida. Translation. Jakarta: Buku Kompas, 2005.

Dobbin, Christine. "Tuanku Imam Bondjol (1772-1864)." Indonesia, Vol. 13, April, 1972.

--------. "Economic Change in Minangkabau as a Factor in the Rise of the Padri Movement, 1784-1830." Indonesia, 23, April 1977.

El Fadl, Khaled Abou. "Toleransi dalam Islam." in Joshua Cohen and Ian Lague (eds). Cita dan Fakta Toleransi Islam: Puritanisme versus Pluralisme. Translation. Bandung: Arasy Mizan, 2003.

Fathurrahman, Oman. "Tarekat Shatariyah di Dunia Melayu-Indonesia: Kajian atas Dinamika dan Perkembangannya melalui Naskahnaskah di Sumatra Barat." Unpublished PhD Dissertation, School of Humanity Studies, Postgraduate Program, The University of Indonesia, Jakarta, 2003.

Foucault, Michel. "Nietzsche, Genealogy, History." in D. F. Bouchard (ed.). Language, Counter-Memory Practice: Selected Essays and Interviews. Ithaca: Cornell University Press, 1977.

Galtung, Johan. "Kekerasan Kultural.” Wacana, 9, III, 2002.

al-Ghazali, Abu Hamid Imam. "Rawdłh al-Tłi wa 'Umdah alSali in Majmu Rasa al-Ima al-Ghaza Kutub al-'Alamiyah, 1986.

Graves, Elisabeth E. Asal Usul Elite Minangkabau Modern: Respons terhadap Belanda Abad XIX/XX. Translation, Jakarta: Yayasan Obor Indonesia, 2007. 
al-Jabiri, Muhammad 'Abid. Qaddłar-al-Fikr al-Arabi:>al-Mas-alab alThaqa)yah. Beirut: Markaz Dirasah al-Wahłah al-'Arabiyyah, 1994.

Khatib, Adrianus. "Kaum Padri dan Pemikiran Keagamaan di Minangkabau." Unpublished Ph.D Dissertation, Postgraduate Program, IAIN Syarif Hidayatullah, Jakarta, 1991.

Lukas, Helmut. "The Perception of Indonesia's History and Culture by Western Historian and Social Scientists." paper presented at the Seminar "Indonesia's Cultural Diversity in Time of Global Change," Indonesian Embassy Brussels, The European Institute for Asia Studies, Brussels, The Royal Academy of Overseas Sciences, Brussels, and The International Institute for Asian Studies, Leiden, 16 December 2002.

Parlindungan, Mangaraja Onggang. Pongkinangolngolan Sinambela Gelar Tuanku Rao: Teror Agama Islam Mą̧bab Hambali di Tanah Batak 1816-1833. Yogyakarta: LKiS, 2007.

Lucius, Robert E. "A House Divided: The Decline and Fall of Masyumi (1950-1956)." Unpublished MA Thesis, the Naval Postgraduate School, California, September 2003.

Lubis, Abdur-Razzaq. "Mandailing Islam Across Borders." Taiwan Journal of Southeast Asian Studies, Vol. 2, No. 2, 2005.

Rahman, Fazlur. Islam and Modernity: Transformation of an Intellectual Tradition. Chicago and London: The University of Chicago Press, 1982.

Ricklefs, M. C. Sejarah Modern Indonesia 1200-2004. Jakarta: PT Serambi Ilmu Semesta, 2005.

--. "Islamizing Indonesia: Religion and Politics in Singapore's Giant Neighbour'." public lecture Asian Civilisations Museum. Asia Research Institute, National University of Singapore, 23 September 2004.

Roy, Olivier. Genealogi Islam Radikal. Translation. Yogyakarta: Genta Press, 2005

Tibi, Bassam. The Challenge of Fundamentalism: Political Islam and the New World Disorder. Berkeley - Los Angeles - London: University of California Press, 1998. 
al-Maliki, Muhammad bin 'Alawi. "al-Ghuluwwu wa A Irha wa Ifsal-Mujtama'." A Compilation of Papers in the National Seminar on al-Gbuluwwu wa al-I'tida Ru'yah Manbajiyyah Sharilah. Mekkah al-Mukarromah, 5-9 Dhul Qa'dah 1424 H.

\section{Electronic Sources}

Djaelani, Abdul Qadir. "Perang Padri." in http://www.mail-chive.com/urangawak@yahoogroups.com/msg00475.html

El Fadl, Khaled Abou. "Islam and Theology of Power." Middle East Report, 221, 2001. in http://www.merip.org/mer/mer221/221abu_el_fadl.html

Katkova, Irina. "Islamic Manuscripts of Western Sumatra, Problem of Investigation and Preservation (on the Materials Field Research Work in Western Sumatra of 2006)." in http://www.islamicmanuscript.org/resources/files/katkova_Irina_TIMA.pdf

Rimac, Melissa. "Matrinial Minangkabau." in http://www.practitionerdirectory.com.au/natural_health_article?cid=751\&pid=1 7365

Suryadi, "Tuanku Imam Bonjol: Dikenang Sekaligus Digugat." in http://naskahkuno.blogspot.com/2007/11/tuanku-imam-bonjoldikenang-sekaligus.html

-.'Kontroversi Kaum Padri: Jika Bukan Karena Tuanku Nan Renceh." in http://naskahkuno.blogspot.com/2007/11/kontroversi-kaum-paderi-jika-bukan.html.

Thaib, Puti Reno Raudha. "Sejarah Istana Pagaruyung." in http://groups.yahoo.com/group/RantauNet/message/61114

\section{Newspapers}

Tempo. 34/XXXVI. 15-21 October 2007.

Azra, Azyumardi. “Salafisme.” Republika. 14 April 2005. 